De Jure: Jurnal Hukum dan Syar'iah

Vol. 12, No. 1, 2020, h. 35-50

ISSN (Print): 2085-1618, ISSN (Online): 2528-1658

DOI: http://dx.doi.org/10.18860/j-fsh.v12i1.9087

Available online at http://ejournal.uin-malang.ac.id/index.php/syariah

\title{
Kesadaran Hukum Masyarakat dalam Akselerasi Sertifikasi Tanah Wakaf di Kota Malang
}

\author{
Sudirman \\ UIN Maulana Malik Ibrahim Malang \\ sudirman@syariah.uin-malang.ac.id \\ Ramadhita \\ UIN Maulana Malik Ibrahim Malang \\ ramadhita@syariah.uin-malang.ac.id
}

\begin{abstract}
:
This research is motivated by the enthusiasm of the Malang City Government to promote the certification of waqf land whose legal status is uncertain. Data shows that certified wakaf land is only $45.6 \%$ while certified wakaf land is still $54.4 \%$. The main purpose of this study is to describe the factors that cause uncertified waqf land in Malang City, to illustrate the real efforts of the Malang City Government to increase public legal awareness, and to analyze the Malang City community's views on endowment land certification. using legal awareness theory. The results showed that the factors behind uncertified waqf land were the low level of legal awareness of the people of Malang City, high costs, and long complicated procedures for obtaining certificates. Therefore, the government has introduced a number of policies to resolve the problem, such as legal education and free registration of waqf land. Finally, the analysis of legal awareness theory shows that the people of Malang City have an intermediate range of legal awareness due to the cognitive level of legal regulation, the content of cognitive level regulation, legal attitude, and legal behavior
\end{abstract}

Keywords: waqf of land; certificate; legal awareness.

\section{Abstrak:}

Penelitian ini dilatarbelakangi oleh antusiasme Pemerintah Kota Malang untuk mempromosikan sertifikasi tanah wakaf yang status hukumnya masih belum pasti. Tujuan artikel ini adalah untuk mendeskripsikan faktor-faktor yang menyebabkan tanah wakaf tidak bersertifikat di Kota Malang, untuk menggambarkan upaya nyata pemerintah Kota Malang untuk meningkatkan kesadaran hukum publik, 
dan untuk menganalisis pandangan masyarakat Kota Malang tentang sertifikasi tanah wakaf. Hasil penelitian menunjukkan bahwa faktorfaktor di balik tanah wakaf tidak bersertifikat adalah rendahnya tingkat kesadaran hukum masyarakat Kota Malang, biaya tinggi, dan prosedur rumit panjang untuk mendapatkan sertifikat. Oleh karena itu, pemerintah telah memperkenalkan beberapa kebijakan untuk menyelesaikan masalah, seperti pendidikan hukum dan pendaftaran gratis untuk tanah wakaf. Akhirnya, analisis teori kesadaran hukum menunjukkan bahwa masyarakat Kota Malang memiliki rentang kesadaran hukum menengah karena tingkat kognitif regulasi hukum, isi regulasi level kognitif, sikap hukum, dan perilaku hukum.

Kata Kunci: waqf tanah; sertifikat; kesadaran hukum

\section{Pendahuluan}

Wakaf merupakan sarana ibadah sekaligus instrumen kesejahteraan bagi umat Islam. ${ }^{1}$ Wakaf menjadi salah satu penopang perekonomian negara, mewujudkan kemandirian ekonomi umat Islam, ${ }^{2}$ serta meningkatkan kualitas pendidikan umat Islam. ${ }^{3}$ Keberhasilan ini menjadikan wakaf masih menjadi objek kajian yang menarik. Terdapat berbagai ragam riset tentang wakaf. Kajian Sudirman, ${ }^{4}$ Havita dan Hakim, ${ }^{5}$ dan Eva Mir'atun Niswah, ${ }^{6}$ Sukamto, ${ }^{7}$ Achmad Noer Maulidi, ${ }^{8}$ menunjukkan adanya perkembangan objek wakaf. Objek wakaf tidak hanya berupa tanah atau bangunan saja, tetapi juga meliputi uang, logam mulia, surat-surat berharga, kendaraan, dan hak kekayaan intelektual. Sementara itu, dalam kaitannya dengan sarana wakaf, studi wakaf sudah masuk pada

\footnotetext{
${ }^{1}$ Heru Susanto, "Maqāṣid Al-Shar̄̄ah on Wakaf System," HUNAFA: Jurnal Studia Islamika 14, no. 2 (December 31, 2017): 327, https://doi.org/10.24239/jsi.v14i2.486.327-345.

${ }^{2}$ Nasrul Fahmi Zaki Fuadi, "Wakaf sebagai Instrumen Ekonomi Pembangunan Islam," Economica: Jurnal Ekonomi Islam 9, no. 1 (July $31, \quad 2018)$ : 153, https://doi.org/10.21580/economica.2018.9.1.2711.

3 Miftahul Huda, "Wakaf Dan Kemandirian Pesantren Dari Tebuireng Hingga Gontor," ISLAMICA: Jurnal Studi Keislaman 7, no. 1 (January 23, 2014): 230, https://doi.org/10.15642/islamica.2012.7.1.211-231.

4 Sudirman Sudirman, "Studi Perbandingan Obyek Wakaf Menurut Fikih Dan Undang-Undang Wakaf," De Jure: Jurnal Hukum Dan Syariah 1, no. 2 (2010): 141, https://doi.org/10.18860/jfsh.v1i2.333.

5 Gusva Havita and Gestivia Hakim, "Wakaf Saham Ditinjau Dari Hukum Islam Dan Peraturanperundang-Undangan Setelah Berlakunya Undang-Undang Nomor 41 Tahun 2004 Tentang Wakaf," JURNAL SYARIKAH : JURNAL EKONOMI ISLAM 3, no. 1 (June 21, 2017): 35871, https://doi.org/10.30997/jsei.v3i1.720.

${ }^{6}$ Eva Mir'atun Niswah, "Problematika Yuridis Wakaf Hak Kekayaan Intelektual Di Indonesia," Volksgeist: Jurnal Ilmu Hukum Dan Konstitusi 1, no. 2 (December 31, 2018): 123-38, https://doi.org/10.24090/volksgeist.v1i2.1907.

7 Sukamto Mei, "Menuju Era Baru Wakaf Tunai (Sebagai Inovasi Finansial Islam dalam Mensejahterakan Umat)," MALIA (TERAKREDITASI) 9, no. 2 (June 5, 2018): 193-212, https://jurnal.yudharta.ac.id/v2/index.php/malia/article/view/1090.

8 Achmad Noer Maulidi, "Wakaf Tunai, Implementasinya dalam Sistem Perbankan Syariah di Indonesia," IQTISHADIA: Jurnal Ekonomi \& Perbankan Syariah 4, no. 2 (December 29, 2017): 23554, https://doi.org/10.19105/iqtishadia.v4i2.1225.
} 
persoalan bank wakaf seperti yang diulas oleh Fahmi Medias. ${ }^{9}$ Kehadiran bank wakaf diharapkan mampu mengurai persoalan kemiskinan di masyarakat. ${ }^{10}$

Aset wakaf saat ini tidak lagi dikelola secara konvensional. Riset Abdurrahman Kasdi, ${ }^{11}$ Naimah $^{12}$, dan Alaiddin Koto dan Wali Saputra, ${ }^{13}$ menunjukkan bawah aset wakaf dikelola secara produktif. Pengelolaan aset wakaf secara produktif diharapkan mampu memaksimalkan potensi wakaf untuk kesejahteraan umat Islam. Wakaf produktif juga di terapkan dinegara sekuler seperti Singapura dan Thailand. Meskipun demikian, kajian Ahmad Siddiq, menunjukkan bahwa pengelolaan wakaf secara produktif menemui beberapa masalah. Seperti adanya bias status kepemilikan aset wakaf, percampuran aset wakaf dan non-wakaf, dan profesionalitas nadzir dalam pengelolaan wakaf. ${ }^{14}$

Wakaf tanah masih mendominasi di Indonesia. Data Sistem Informasi Wakaf (Siwak) Kementerian Agama Republik Indonesia menunjukkan bahwa aset tanah wakaf sejumlah 51.261,14 Ha yang tersebar di 382.318 lokasi. Dari jumlah tersebut, $61,12 \%$ sudah bersertifikat wakaf. Aset wakaf digunakan untuk tempat ibadah, makam, pondok pesantren, atau lembaga pendidikan. ${ }^{15}$ Aset yang belum bersetifikat wakaf berpotensi menimbulkan masalah. Sebagaimana riset Nur Fadhilah, ${ }^{16}$ Hendrawati \& Islamiyati, ${ }^{17}$ Syahputra \& Khalid, ${ }^{18}$ Yose Leaonardo, ${ }^{19}$ dan Arifin. ${ }^{20}$ Beberapa problem yang muncul antara lain dimintanya kembali aset

\footnotetext{
9 Fahmi Medias, "Bank Wakaf: Solusi Pemberdayaan Sosial Ekonomi Indonesia," Indonesian Journal of Islamic Literature and Muslim Society 2, no. 1 (June 30, 2017): 61-84, https://doi.org/10.22515/islimus.v2i1.749.

${ }^{10}$ Hari Sutra Disemadi and Kholis Roisah, "Kebijakan Model Bisnis Bank Wakaf Mikro Sebagai Solusi Pemberdayaan Ekonomi Masyarakat," LAW REFORM 15, no. 2 (September 30, 2019): 177, https://doi.org/10.14710/lr.v15i2.26176.

${ }^{11}$ Abdurrahman Kasdi, "Reinterpretasi Konsep Wakaf Menuju Pengembangan Wakaf Produktif," ZISWAF: Jurnal Zakat Dan Wakaf 2, no. 1 (August 19, 2016): 159-75, https://doi.org/10.21043/ziswaf.v2i1.1540.

12 Naimah Naimah, "Implemetasi Yuridis Terhadap Kedudukan Wakaf Produktif Berbasis Peningkatan Ekonomi Masyarakat Di Indonesia," At-Taradhi: Jurnal Studi Ekonomi 9, no. 1 (August 1, 2018): 10-24, https://doi.org/10.18592/at-taradhi.v9i1.2093.

${ }^{13}$ Alaiddin Koto and Wali Saputra, "Wakaf Produktif Di Negara Sekuler: Kasus Singapura Dan Thailand," Sosial Budaya 13, no. 2 (May 29, 2017): 116-39, https://doi.org/10.24014/sb.v13i2.3535.

${ }^{14}$ Achmad Siddiq, "Wakaf Produktif Dan Problematikanya Di Dunia Pesantren," Millah: Jurnal Studi Agama 11, no. 1 (2011): 285, https://doi.org/10.20885/millah.vol11.iss1.art14.

${ }^{15}$ Kementerian Agama RI, "Jumlah Tanah Wakaf Seluruh Indonesia," SIWAK KEMENAG RI, accessed May 12, 2019, http://siwak.kemenag.go.id/tabel_jumlah_tanah_wakaf.php.

${ }^{16}$ Nur Fadhilah, "Sengketa Tanah Wakaf Dan Strategi Penyelesaiannya," De Jure: Jurnal Hukum Dan Syar'iah 3, no. 1 (June 1, 2011), https://doi.org/10.18860/j-fsh.v3i1.1321.

${ }^{17}$ Dewi Hendrawati and Islamiyati Islamiyati, "Penyelesaian Sengketa Tanah Wakaf Yang Tidak Tersertifikasi Di Wilayah Pesisir Utara Jawa Tengah," Masalah-Masalah Hukum 47, no. 1 (January 30, 2018): 71-80-80, https://doi.org/10.14710/mmh.47.1.2018.71-80.

18 Akmaluddin Syahputra and Khalid Khalid, "Sengketa Tanah Wakaf di Sumatera Utara (Systematic Literature Review Terhadap Pemberitaan Media Online)," Halu Oleo Law Review 4, no. 1 (March 18, 2020): 13-24, https://doi.org/10.33561/holrev.v4i1.11525.

${ }^{19}$ Yose Leonando, "Penyelesaian Sengketa Wakaf Tanah Di Kecamatan Bayang Oleh Pengadilan Agama Kelas Ii Painan Kabupaten Pesisir Selatan," Al Hurriyah: Jurnal Hukum Islam 4, no. 2 (December 16, 2019): 178-191-191, https://doi.org/10.30983/alhurriyah.v4i2.1632.

${ }^{20}$ Mohammad Syamsul Arifin, "Peranan Badan Wakaf Indonesia Dalam Penyelesaian Sengketa Tanah Wakaf," Jurnal Hukum dan Kenotariatan 4, no. 1 (March 7, 2020): 27-40, https://doi.org/10.33474/hukeno.v4i1.6446.
} 
wakaf oleh ahli waris, aset dijual kepada pihak ketiga, penguasaan aset wakaf oleh keluarga nadzir secara turun temurun, serta aset wakaf yang tidak terawat dengan baik oleh nadzir. ${ }^{21}$

Persoalan sertifikasi tanah wakaf juga ditemui di Kota Malang. Tanah wakaf di Kota Malang seluas 21,20 Ha. Dari jumlah tersebut, aset wakaf yang sudah bersertifikat hanya $45,6 \%$. Sedangkan $54,4 \%$ belum memiliki kejelasan status. ${ }^{22}$ Data di atas menunjukkan bahwa 2/3 tanah wakaf di Kota Malang belum memiliki kekuatan hukum. Padahal, sudah selayaknya praktik wakaf di Kota Malang sudah berkembang pada objek selain tanah, seperti wakaf uang, properti atau hak kekayaan intelektual. Mengingat tingkat perkembangan keagamaan, ekonomi, dan pendidikan di Kota Malang sudah mengalami perkembangan signifikan. ${ }^{23}$ Untuk itu, aspek tanah wakaf harus segera dituntaskan sehingga masyarakat dapat melaksanakan jenis-jenis wakaf lainnya. Pemerintah Kota Malang juga memiliki komitmen untuk menyelesaikan problem wakaf tanah di wilayahnya. Keinginan ini pernah diungkapkan oleh Walikota Malang, Sutiaji. Walikota yang menjabat tahun 2018-2023 ini berkomitmen menuntaskan persoalan wakaf di wilayahnya agar sengketa wakaf yang sering terjadi di masyarakat dapat dihindari. ${ }^{24}$

Artikel ini merupakan hasil penelitian yuridis empiris dengan pendekatan sosiologis. Sumber data penelitian adalah stakeholder yang berkaitan dengan wakaf seperti pemerintah Kota Malang, Badan Wakaf Indonesia Kota Malang, Organisasi Masyarakat Islam yang mengelola wakaf, Majelis Ulama Indonesia Kota Malang, serta 52 pengurus masjid di Kota Malang. Artikel ini bertujuan mendeksripsikan problematika sertifikasi tanah wakaf, kesadaran hukum masyarakat dalam proses sertifikasi, dan upaya akselerasi sertifikasi tanah wakaf di Kota Malang. Artikel ini berargumen bahwa kesadaran hukum memiliki peranan penting dalam akselerasi sertifikasi tanah wakaf di Kota Malang. Kesadaran hukum masyarakat berkaitan erat dengan pendidikan dan sosialisasi yang diterima masyarakat dari stakeholder sertifikasi wakaf.

\section{Problem Sertifikasi Tanah Wakaf di Kota Malang}

Wakaf tanah di Kota Malang masih menemui sejumlah kendala. Problem ini sebagian besar disebabkan aset wakaf belum memiliki sertifikat sebelumnya. Ada dua faktor utama penyebab problem sertifikasi tanah wakaf di Kota Malang. Pertama, Pengetahuan Masyarakat tentang wakaf masih kurang. Masyarakat masih menganggap bahwa wakaf merupakan masalah ibadah dan tidak terkait dengan persoalan administrasi. Tidak jarang penyerahan aset wakaf kepada nadzir tanpa dilengkapi dengan Akta Ikrar Wakaf (AIW) yang dibuat oleh Kantor Urusan Agama (KUA). Tidak adanya AIW menyebakan program sertifikasi tanah wakaf oleh Pemerintah melalui Kementerian ATR/BPN tidak berjalan secara maksimal. Meruntut Hamdani, ketua Badan Pertanahan Kota Malang pemerintah berupaya

\footnotetext{
${ }^{21}$ Hendrawati and Islamiyati, "Penyelesaian Sengketa Tanah Wakaf," 71.

22 Kementerian Agama RI, "Data Tanah Wakaf Kota Malang," accessed May 11, 2019, http://siwak.kemenag.go.id/tanah_wakaf_kab.php?prov=35\&kab=32.

${ }^{23}$ Badan Pusat StatistiASk Kota Malang, Kota Malang Dalam Angka 2019 (Malang: BPS Kota Malang, 2019).

${ }^{24}$ Abdi, "Kejar Bedah Rumah Dan Sertifikasi Tanah Wakaf," Malang Post Online, accessed December 16, 2018, https://www.malangpostonline.com/read/8619/kejar-bedah-rumah-dansertifikasi-tanah-wakaf.
} 
melegalkan aset wakaf melalui program Pemetaan Tanah Sistematis Lengkap (PTSL). Namun sering kali nadzhir atau wakif tidak dapat menunjukkan AIW sebagai syarat utama pengurusan sertifikat tanah wakaf. ${ }^{25}$

Pengurus MUI Kota Malang, Chamzawi, juga setuju dengan pernyataan Hamdani. Chamzawi berpendapat bahwa masyarakat secara umum kurang paham tentang peraturan wakaf yang berlaku, hanya sebatas faham dari penjelesan kitab fiqih yang ada. ${ }^{26}$ Pengurus Badan Wakaf Indonesia Perwakilan Kota Malang, Shamthon, juga menegaskan bahwa pengetahuan wakaf masyarakat masih lemah dan hanya dimiliki oleh pengurus saja, semisal nazhir. ${ }^{27} \mathrm{Hal}$ berbeda disampaikan oleh Pengurus Cabang Nahdlatul Ulama (PCNU) Kota Malang. Dalam hal ini, Mahmudi selaku wakil ketua yang membidangi wakaf membedakan dua kelompok masyarakat, yakni: masyarakat yang mendapat sosialisasi peraturan wakaf dan masyarakat yang tidak mendapat sosialisasi peraturan wakaf. Menurut Mahmudi, masyarakat yang mendapat sosialisasi cenderung lebih tertib dan bersemangat untuk melakukan sertifikasi. Sebaliknya, masyarakat yang tidak mendapat sosialisasi biasanya tidak peduli dengan pengurusan sertifikat wakaf. ${ }^{28}$ Dari pernyataan di atas dapat disimpulkan bahwa pengetahuan masyarakat tentang sertifikasi wakaf sangat tergantung kepada informasi yang mereka terima. Semakin banyak dan intensif sosialisasi wakaf kepada masyarakat, semakin tinggi pula pengetahuan mereka terutama tentang prosedur sertifikasi.

Kedua, Kompleksitas Masalah Wakaf di Kota Malang. Pemerintah sudah memberikan ruang bagi para nadzir untuk mensertifikatkan aset wakaf secara mudah dan tanpa biaya. Namun kebijakan ini terkendala oleh kelengkapan syarat pengurusan sertifikat. ${ }^{29}$ Berdasarkan Peraturan Menteri Agraria dan Tata Ruang/ Kepala Badan Pertanahan Nasional Republik Indonesia Nomor 2 Tahun 2017 tentang Tata Cara Pendaftaran Tanah Wakaf di Kementerian Agraria dan Tata Ruang/Badan Pertanahan Nasional dinyatakan bahwa permohonan sertifikat tanah wakaf untuk tanah yang berstatus hak milik dengan syarat sebagai berikut: a) surat permohonan; b) surat ukur; c) sertipikat Hak Milik yang bersangkutan; d) AIW atau APAIW; e) surat pengesahan Nazhir yang bersangkutan dari instansi yang menyelenggarakan urusan agama tingkat kecamatan; dan f) surat pernyataan dari Nazhir bahwa tanahnya tidak dalam sengketa, perkara, sita dan tidak dijaminkan. Sedangkan untuk tanah yang berstatus tanah adat atau tanah ulayat maka diberlakukan syarat sebagai berikut: 1) surat permohonan; 2) Peta Bidang Tanah/Surat Ukur; 3) bukti kepemilikan tanah yang sah; 4) AIW atau APAIW; 5) surat pengesahan Nazhir yang bersangkutan dari instansi yang menyelenggarakan urusan agama tingkat kecamatan; dan 5) Surat pernyataan dari Nazhir/Wakif atau surat keterangan dari Kepala Desa/Lurah/tokoh masyarakat bahwa tanahnya tidak dalam sengketa, perkara, sita dan tidak dijaminkan. ${ }^{30}$

\footnotetext{
${ }^{25}$ Hamdani, Wawancara, (Malang: 14 Juli 2019)

${ }^{26}$ Chamzawi, Wawancara, (Malang:15 Juli 2019)

${ }^{27}$ Shamthon, Wawancara, (Malang: 18 Juli 2019)

${ }^{28}$ Mahmudi, Wawancara, (Malang: 16 Juli 2019)

${ }^{29}$ Hamdani, Wawancara, (Malang: 14 Juli 2019)

30 Peraturan Menteri Agraria dan Tata Ruang/ Kepala Badan Pertanahan Nasional Republik Indonesia Nomor 2 Tahun 2017 tentang Tata Cara Pendaftaran Tanah Wakaf di Kementerian Agraria dan Tata Ruang/Badan Pertanahan Nasional
} 
Terkait dengan bukti kepemilikan tanah, sebagian besar tanah wakaf bukti kepemilikannya berupa Letter C/Girik, Petuk D, atau Ketitir. Menurut Oktaviani dan Harjono Letter $C$ tidak masuk sebagai alat bukti yang dapat berdiri sendiri. Jika terjadi sengketa maka keberadaannya harus didukung oleh alat bukti lain. ${ }^{31}$ Penelitian Hidayanti dkk. menyebutkan bahwa akta yang dibuat oleh notaris dapat dijadikan alat bukti jika terjadi sengketa. ${ }^{32}$ Dengan adanya akta notaris proses menuju sertifikasi hak atas tanah menjadi lebih mudah. Namun, pembuatan akta ini juga membutuhkan biaya yang tidak murah. Terlebih aset yang akan disertifikatkan cukup luas dan memiliki nilai jual yang mahal.

Kendala lain yang sering sekali menghambat adalah tentang biaya pengurusan sertifikasi yang cukup tinggi, sebagaimana pengalaman Mahmudi dalam proses sertifikasi aset wakaf. $^{33}$ Pengurus Majelis Ulama Indonesia, Chamzawi, mencontohkan tanah wakaf yang berasal dari pembagian waris membutuhkan waktu dan biaya yang banyak. Tidak jarang bahkan muncul sengketa antar ahli waris. Berbelitnya administrasi. Sumber dana untuk menyelesaikan administrasi sertifikat wakaf. Masalah sertifikasi wakaf harus ada ikut campur dari pemerintah atau pihak yang berkewenangan. Karena administrasi yang panjang dan dana yang tidak sedikit untuk menyelesaikan sertifikasi wakaf. ${ }^{34}$

Masalah yang dihadapi masyarakat menurut Chamzawi sebagai pernyataan di atas adalah pemahaman masyarakat yang rendah, administrasi yang rumit, dan sumber pendanaan yang kurang. Oleh sebab itu, pemerintah harus terlibat dalam pengurusan wakaf. Hal serupa disampaikan oleh Pengurus Daerah Muhammadiyah. Masyarakat masih menganggap bahwa wakaf cukup disampaikan secara lisan. Meskipun ada beberapa yang melanjutkan sampai proses sertifikasi. Proses yang cukup panjang untuk mendapat legalitas dari status tanah, apalagi jika berhubungan dengan harta warisan. Bahkan terkadang satu lokasi belum bisa tuntas dalam waktu satu tahun. Selain itu, biaya pajak juga tinggi. Sementara anggaran di Muhammadiyah terbatas. ${ }^{35}$

Dari pernyataan Syarif dapat diketahui bahwa masalah yang dihadapi oleh masyarakat dalam pengurusan wakaf adalah kebiasaan wakaf secara lisan, terbatasnya anggaran, waktu pengurusan wakaf yang panjang dan biaya pajak. Terakhir, Shamthon selaku pengurus BWI dan juga pernah menjabat sebagai Kepala KUA menegaskan tidak ada alokasi dana khusus sertifikasi wakaf di KUA. Kurangnya sumber daya manusia juga menjadi kendala. Tidak ada staff khusus yang secara intensif menangani persoalan wakaf. Hal ini menjadikan pendataan wakaf terkendala. Itu merupakan fakta yang hampir terjadi di KUA seluruh Indonesia. ${ }^{36}$ Sementara itu, Murtadho selaku Ketua Asosiasi Nadhir Wakaf Kota Malang menyebutkan masalah yang lain. Nadzir tidak punya cukup waktu untuk

\footnotetext{
31 Annisa Oktaviani and Harjono Harjono, "Kekuatan Pembuktian Surat Letter C Dalam Pemeriksaan Sengketa Tanah di Persidangan," Verstek 7, no. 1 (May 15, 2019): 46, https://jurnal.uns.ac.id/verstek/article/view/30038.

${ }^{32}$ Anisa Rahma Hadiyanti, Rachmad Safa'at, and Tunggul Anshari, "Kedudukan Akta Hibah Dalam Sengketa Kepemilikan Hak Atas Tanah,” Lentera Hukum 4, no. 3 (December 14, 2017): 205-20, https://doi.org/10.19184/ejlh.v4i3.5316.

${ }^{33}$ Mahmudi, Wawancara, (Malang: 16 Juli 2019)

${ }^{34}$ Chamzawi, Wawancara, (Malang: 15 Juli 2019)

${ }^{35}$ Syarif, Wawancara, (Malang: 17 Juli 2019)

${ }^{36}$ Shamthon, Wawancara, (Malang: 18 Juli 2019)
} 
sertifikasi aset wakaf. Selain itu, instansi yang dihubungi juga sangat banyak, seperti KUA, BWI, dan BPN. ${ }^{37}$ Dari pernyataan di atas dipahami bahwa masalah yang menjadi kendala untuk sertifikasi wakaf adalah kurangnya alat bukti wakaf dan kesibukan nazhir sehingga wakaf tidak sempat disertifikatkan. Selain itu, masalah lainnya adalah banyaknya lembaga yang harus ditemui sehingga memperlambat pengurusan wakaf.

\section{Potret Kesadaran Hukum Masyarakat Kota Malang dalam Sertifikasi Tanah Wakaf}

Problem wakaf tanah di Kota Malang memiliki keterkaitan erat dengan tingkat kesadaran hukum masyarakat. Kesadaran hukum merupakan kesadaran yang ada pada setiap manusia tentang apa hukum itu hukum atau apa seharusnya hukum itu. Kesadaran hukum merupakan kondisi kejiwaan manusia yang dapat membedakan antara hukum dan atau bukan hukum. Kesadaran hukum juga dapat memberikan panduan bagi manusia untuk membedakan antara yang seharusnya dilakukan atau ditinggalkan. Krabbe sebagaimana dikutip oleh Laurensius Arliman menyatakan bahwa sumber dari segala hukum adalah kesadaran hukum. Produk hukum yang tidak sesuai dengan kesadaran hukum kebanyakan orang akan kehilangan daya ikatnya. ${ }^{38}$ Kesadaran hukum merupakan nilai yang hidup di masyarakat sebagai wujud pemahaman dan kepatuhan masyarakat terhadap hukum yang berlaku. ${ }^{39}$

Menurut Von Schmid, kesadaran hukum (rechtsbewutzijn) yaitu penilaian seseorang terhadap hukum, yang berawal dari penalaran logis. ${ }^{40}$ Kesadaran hukum juga dapat diartikan sebagai keadaan seseorang yang tahu betul apa itu hukum, fungsi dan peranan hukum bagi diri sendiri dan masyarakat sekitar. Menurut Sudikno Mertokusumo sebagaimana dikutip oleh Amran Suadi menyatakan bahwa kesadaran hukum lahir dari kehendak bersama umat manusia untuk mencegah terjadinya konflik kepentingan dalam kehidupan sehari-hari. ${ }^{41}$ Adapun menurut Soekanto, kesadaran hukum merupakan kesadaran atau nilai-nilai yang terdapat di dalam diri manusia tentang hukum yang ada atau tentang hukum yang diharapkan ada. Sebenarnya yang ditekankan adalah nilai-nilai tentang fungsi hukum dan bukan suatu penilaian hukum terhadap kejadian-kejadian yang konkrit dalam masyarakat yang bersangkutan. Kesadaran hukum masyarakt dapat diukur menggunakan sejumlah indicator yang meliputi Pengetahuan tentang peraturan, Pengetahuan tentang isi peraturan, Sikap terhadap peraturan, dan Perilaku yang sesuai dengan peraturan. ${ }^{42}$

\footnotetext{
${ }^{37}$ Murtadho, Wawancara, (Malang: 17 Juli 2019)

${ }^{38}$ Laurensius Arliman, Penegakan Hukum dan Kesadaran Masyarakat (Yogyakarta: Deepublish, 2015), 220-21.

39 M Mulhadi and Zulfi Chairi, "Analisa Yuridis Terhadap Kesadaran Hukum Berasuransi Pedagang Di Lingkungan Pasar Kota Medan," Mimbar Hukum 29, no. 2 (September 30, 2017): 238, https://doi.org/10.22146/jmh.17642.

40 C. F. G. Sunaryati Hartono, Peranan Kesadaran Hukum Masyarakat Dalam Pembaharuan Hukum (Bandung: Bina Cipta, 1976), 3.

${ }^{41}$ Amran Suadi, Sosiologi Hukum: Penegakan, Realitas, Dan Nilai Moralitas Hukum (Jakarta: Kencana, 2018), 192-93.

42 Soerjono Soekanto, "Kesadaran Hukum Dan Kepatuhan Hukum," Jurnal Hukum \& Pembangunan 7, no. 6 (December 31, 1977): 468-468, https://doi.org/10.21143/jhp.vol7.no6.742.
} 
Terkait dengan kesadaran hukum wakaf di Kota Malang, hasil survey menunjukkan bahwa masyarakat belum sepenuhnya mengetahui berbagai regulasi perwakafan yang ada. Sebagaimana hasil survey yang dilakukan terhadap 52 orang takmir masjid di Kota Malang. ${ }^{43}$ Hasil survey secara umum menunjukkan bahwa para takmir masjid masih memahami bahwa wakaf telah selesai jika sudah sah secara fiqih. Berikut sebaran data para takmir masjid di Kota Malang yang menjadi responden.

Tabel 1. Responden Angket Wakaf

\begin{tabular}{lll}
\hline No & Kecamatan & Jumlah \\
\hline 1 & Sukun & 11 \\
\hline 2 & Klojen & 8 \\
\hline 3 & Blimbing & 18 \\
\hline 4 & Kedung kendang & 8 \\
\hline 5 & Lowokwaru & 7 \\
\hline Jumlah & $\mathbf{5 2}$ \\
\hline
\end{tabular}

Berdasarkan hasil survey diketahui bahwa: Pertama, Pengetahuan Masyarakat tentang Peraturan di bidang perwakafan. Hasil survey menunjukkan bahwa masyarakat Kota Malang telah mengetahui bahwa di Indonesia telah ada peraturan khusus yang mengatur tentang wakaf. $42 \%$ responden memilih setuju dan $53 \%$ dari mereka sangat setuju. Ini berarti $95 \%$ responden mengakui adanya peraturan wakaf di Indonesia. Sebaliknya, 2\% responden mengaku tidak setuju adanya peraturan wakaf di Indonesia dan 3\% di antara mereka yang masih ragu tentang keberadaan peraturan tersebut. Sebagaimana data dalam tabel berikut.

Tabel 2. Pengetahuan tentang Peraturan Wakaf

\begin{tabular}{lll}
\hline Pilihan & Jumlah & Prosentase \\
\hline Sangat Tidak Setuju & 1 & $2 \%$ \\
\hline Tidak Setuju & 0 & $0 \%$ \\
\hline Ragu-ragu & 2 & $3 \%$ \\
\hline Setuju & 23 & $42 \%$ \\
\hline Sangat Setuju & 29 & $53 \%$ \\
\hline Abstein & 0 & $0 \%$ \\
\hline
\end{tabular}
${ }^{43}$ Jumlah 52 takmir masjid yang dipilih merupakan hasil komunikasi dan koordinasi dengan Bidang
Sejahteraan Rakyat Pemerintahan Kota Malang. Masjid di Kota Malang berjumlah 660 buah. 
Meskipun demikian, hanya sedikit responden yang benar-benar mengetahui regulasi wakaf di Indonesia. Dari 52 responden, hanya 5\% yang mengetahui bahwa wakaf diatur dalam Undang-Undang Nomor 41 tahun 2004. Sedangkan 38\% responden benar-benar tidak tahu nama peraturan wakaf. Data yang menarik ditemukan dalam angket ini bahwa responden yang ragu-ragu jumlahnya cukup tinggi, yakni 33\%. Responden yang menyatakan abstain berjumlah $24 \%$. Hal ini menunjukkan bahwa lebih dari separuh responden memposisikan diri mereka sebagai orang yang tidak yakin. Dan dapat juga dimaknai orang yang tidak tahu. Berdasarkan hal ini, ada indikasi kuat bahwa mayoritas masyarakat Kota Malang tidak mengetahui undang-undang yang mengatur tentang wakaf.

Kedua, Pengetahuan masyarakat tentang isi peraturan tentang wakaf juga masih perlu ditingkatkan. Mayoritas responden dengan jumlah $65 \%$ setuju dengan pernyataan bahwa wakaf berjangka tidak diizinkan dalam peraturan perundangundangan wakaf. Meskipun dalam Undang-Undang 41 Tahun 2004, wakaf berjangka diperbolehkan. Data tersebut dapat dilihat dalam tabel berikut.

Tabel 3 Wakaf Berjangka

\begin{tabular}{lll}
\hline \multicolumn{1}{c}{ Pilihan } & Jumlah & Prosentase \\
\hline Sangat Tidak Setuju & 5 & $9 \%$ \\
\hline Tidak Setuju & 6 & $11 \%$ \\
\hline Ragu-ragu & 7 & $13 \%$ \\
\hline Setuju & 19 & $34 \%$ \\
\hline Sangat Setuju & 17 & $31 \%$ \\
\hline Abstein & 1 & $2 \%$ \\
\hline
\end{tabular}

Terkait dengan pengelola wakaf, hasil survey menunjukkan bahwa $89 \%$ responden sepakat bahwa jenis nazhir ada tiga, yakni perorangan, badan hukum, dan organisasi. Hal ini menunjukkan bahwa pengetahuan masyarakat tentang jenis nazhir sangat bagus. Terkait dengan jenis-jenis aset wakaf hasil survey menunjukkan bahwa 100\% mengetahui bahwa wakaf dapat berupa benda bergerak dan wakaf benda tidak bergerak. Hal ini sesuai dengan aturan yang berlaku di Indonesia. Dengan demikian, pengetahuan masyarakat tentang jenis wakaf cukup tinggi. Terkait dengan wakaf uang, 51\% responden setuju bahwa wakaf uang diperbolehkan di Indonesia. Adapun responden yang menyatakan tidak setuju berjumlah $22 \%$ dan responden yang menjawab sangat tidak setuju sebanyak $11 \%$. Ini berarti bahwa 33\% responden tidak setuju bahwa wakaf uang diperbolehkan. Dengan demikian, pengetahuan masyarakat tentang wakaf kontemporer, khususnya wakaf uang, cukup tinggi.

Ketiga, sikap responden terhadap implementasi peraturan wakaf sudah baik. $81 \%$ responden sepakat bahwa aset wakaf harus digunakan untuk kepentingan umum, bukan pribadi. Meskipun demikian, masih ada sekitar 12\% responden yang setuju penggunaan aset wakaf untuk kepentingan pribadi nazhir. Dari sini dapat 
disimpulkan bahwa pengetahuan masyarakat tentang penggunaan aset wakaf cukup bagus. Berkaitan dengan prosedur sertifikasi tanah wakaf, 62\% responden tidak setuju bahwa prosedur wakaf mudah dan murah. Data tersebut dirinci sebagaimana tabel berikut.

Tabel 4 Prosedur Wakaf

\begin{tabular}{lll}
\hline \multicolumn{1}{c}{ Pilihan } & Jumlah & Prosentase \\
\hline Sangat Tidak Setuju & 3 & $6 \%$ \\
\hline Tidak Setuju & 9 & $16 \%$ \\
\hline Ragu-ragu & 19 & $35 \%$ \\
\hline Setuju & 17 & $31 \%$ \\
\hline Sangat Setuju & 4 & $7 \%$ \\
\hline Abstein & 3 & $5 \%$ \\
\hline
\end{tabular}

Keempat, Perilaku masyarakat dalam berwakaf perlu ditingkatkan. Data survey menjunjukkan 49\% responden masih merasa perlu mencari ilmu tentang pengelolaan wakaf yang baik sedangkan $15 \%$ merasa sudah memiliki cukup kompetensi di bidang wakaf. Adapun perilaku takmir masjid terhadap sertifikasi tanah wakaf ditunjukkan dengan data berikut. 49\% responden bersemangat untuk segera memperoleh sertifikat wakaf untuk aset yang dikelola sedangkan sisanya $27 \%$ menyatakan tidak bersemangat, 20\% merasa ragu-ragu, dan 4\% abstein.

Dari data angket yang telah disajikan di atas, dapat disimpulkan bahwa kesadaran hukum masyarakat dengan empat indikator adalah sebagai berikut.

$\begin{array}{lcc}\text { Pengetahuan tentang peraturan } & : & 59,5 \% \\ \text { Pengetahuan tentang isi peraturan } & : & 64 \% \\ \text { Perilaku terhadap peraturan } & : & 76 \% \\ \text { Implementasi terhadap peraturan } & : & 72 \% \\ \text { Skor rata-rata } & & 67,9 \%\end{array}$

Pengetahuan masyarakat tergolong rendah, hanya 59,5\% responden mengetahui peraturan wakaf yang berlaku di Indonesia. Banyak masyarakat yang tidak mengerti nama undang-undang wakaf. Adapun pengetahuan masyarakat tentang isi peraturan juga tidak terlalu tinggi, hanya $64 \%$ responden yang mengerti isi peraturan wakaf. Adapun sikap masyarakat tergolong cukup baik dengan komposisi $76 \%$ responden memiliki sikap yang tepat terhadap sertifikasi wakaf. Hal ini menunjukkan bahwa sikap masyarakat terhadap wakaf yang baik ini dapat menjadi landasan untuk pengembangan wakaf lebih lanjut. Terakhir, perilaku masyarakat terhadap sertifikasi wakaf cukup tinggi dengan komposisi $72 \%$. Hal ini 
juga menjadi modal sosial yang signifikan demi percepatan sertifikasi tanah wakaf di Kota Malang. Kesimpulannya, nilai kesadaran hukum masyarakat jika dibuat rata-ratanya adalah $67,9 \%$. Angka ini memang belum terlalu tinggi sehingga dapat dipahami bahwa sertifikasi tanah wakaf di Kota Malang belum terealisasi secara tuntas karena kesadaran hukum masyarakat belum maksimal. Dari sini dapat dipahami bahwa revitalisasi kesadaran hukum menjadi penting dilakukan.

\section{Upaya Revitalisasi Kesadaran Hukum Masyarakat untuk Akselerasi Sertifikasi Tanah Wakaf di Kota Malang}

Terkait dengan revitalisasi kesadaran hukum masyarakat dilakukan dengan beberapa tahap. Pertama, sinergi antar lembaga yang berkaitan dengan wakaf secara komprehensif. Banyak lembaga yang berkaitan dengan wakaf tanah. Namun, kinerja berbagai lembaga ini terkesan sporadis dan terpisah. Jika semua lembaga bekerja sama sesuai dengan tugas dan fungsinya, upaya untuk akselerasi sertifikasi akan mudah terwujud. Misalnya, BPN mempermudah prosedur sertifikasi wakaf dan Kementerian Agama rajin memberikan penyuluhan dan pembinaan kepada wakif dan nazhir. Sinergi lembaga atau instansi dan sosialisasi yang masif kepada masyarakat menjadi kunci utama akselerasi sertifikasi tanah wakaf. Sebagaimana rekomendasi Cucu Solihah dkk. ${ }^{44}$

Pemerintah Pusat melalui Kementerian Agama, Kementerian ATR/Badan Pertanahan Nasional, dan Pemerintah Daerah memiliki peran strategis dalam akselerasi sertifikasi tanah wakaf. Peran ini dipat dilakukan dengan adanya program pembebasan biaya pengurusan syarat-syarat sertifikat tanah wakaf seperti yang dilakukan Pemerintah Kota Tanggerang. Berdasarkan Peraturan Daerah Kota Tanggerang Nomor 4 Tahun 2018 dinyatakan bahwa tarif Bea Perolehan Hak Atas Tanah dan Bangunan untuk aset wakaf sebesar 0\%. ${ }^{45}$ Selain itu, pemerintah melalui Kementerian ATR/Badan Pertanahan Nasional juga memberikan ruang akselerelasi sertifikasi tanah wakaf melalui program Pemetaan Tanah Sistematis Lengkap (PTSL) dengan biaya 0 rupiah. ${ }^{46}$

Berbagai lembaga di Kota Malang terus menjalin sinergi dalam rangka akselerasi sertifikasi tanah wakaf. Di antaranya pembuatan akta kesepakatan antara BPN Kota Malang dengan Nahdhatul Ulama Kota Malang dan Muhammadiyah Kota Malang. Sebagai tindak lanjut dari kesepakatan ini, tanah yang sudah memiliki sertifikat tidak dipungut biaya ketika didaftarkan di BPN. Meskipun demikian, BPN tidak dapat memberikan pembebasan pajak yang harus ditanggung karena sudah ada aturan tersendiri. ${ }^{47}$ Sinergi antar lembaga juga dilakukan antara Kementerian Agama Kota Malang dengan Nahdhatul Ulama dan Muhammadiyah. Sinergi ini ditindaklanjuti dengan adanya bantuan biaya

\footnotetext{
${ }^{44}$ Cucu Solihah, Dedi Mulyadi, and Hilman Nur, "Muhammadiyah Nazhir Organization Analysis of Waqf Management and Development in Cianjur," Jurnal Dinamika Hukum 17, no. 2 (May 31, 2017): 130, https://doi.org/10.20884/1.jdh.2017.17.2.702.

45 Pasal 80 Peraturan Daerah Kota Tenggerang Nomor 4 Tahun 2018 tentang Perubahan Kedua Atas Peraturan Daerah Nomor 7 Tahun 2010 tentang Pajak Daerah

${ }^{46}$ Hany Saidah, "Program Percepatan Sertifikasi Tanah Wakaf Untuk Pengamanan Aset Wakaf: Studi Di Kantor Kementerian Agama Kota Batu," Sakina: Journal of Family Studies 3, no. 2 (July 24, 2019): 10, http://urj.uin-malang.ac.id/index.php/jfs/article/view/272.

${ }^{47}$ Hamdani, Wawancara, (Malang: 14 Juli 2019)
} 
sertifikasi tanah wakaf dari Kementerian Agama untuk 14 titik. ${ }^{48}$ Sementara itu, Muhammadiyah sebenarnya sudah menganggarkan dana untuk penyelesaian sertifikasi aset wakaf. Meskipun demikian, dana yang dimiliki masih terbatas. Sehingga Muhammadiyah juga memanfaatkan program-program bantuan biaya sertifikasi dari Kementerian Agama. Namun jumlah aset yang tersertifikasi tanah wakaf masih sangat terbatas, satu tahun maksimal hanya lima bidang.

Pengurus Muhammadiyah juga pernah meminta pembebasan atau keringanan pajak BPHTB ke Pemerintah Kota Malang untuk aset wakaf yang akan disertifikasikan. Meskipun demikian, tidak semua dikabulkan, hanya ada satu atau dua aset wakaf saja. ${ }^{49}$ Upaya akselerasi juga dilakukan dengan jalinan komunikasi antar lembaga. ${ }^{50}$ Adapun cara kerjasama Nahdhatul Ulama misalnya, sering melakukan tukar informasi, silaturrahim dan konsultasi ke BPN Kota Malang jika menerui kesulitan. Selain itu, juga aktif bekerjasama dengan kelurahan dan lima Kepala KUA se-Kota Malang. ${ }^{51}$ Adapun Muhammadiyah, selain berkerjasama dengan BPN Kota Malang. Pengrus Daerah yang membidangi wakaf terus melakukan komunikasi dengan Pimpinan Cabang di Kecamatan. Kemudian dari Pimpinan Cabang diteruskan ke tingkat Ranting secara internal. ${ }^{52}$

Kedua, penyelesaian persoalan wakaf tanah. Wakaf sering menimbulkan masalah baik bagi wakif, nazhir, maupun pemerintah. Wakaf tanah yang bertujuan menambah aset untuk kemashlahatan umat ternyata sering menumbulkan konflik di masyarakat. Persoalan wakaf tanah harus diselesaikan dari hulu hingga hilir secara tuntas. Biaya sertifikasi membuat banyak tanah wakaf tidak tersertifikat. Wakif tidak mau mengeluarkan biaya sedangkan nazhir tidak mampu menggalang dana untuk menanggung biaya sertifikasi. Selain biaya, kendala lainnya adalah sengketa wakaf dalam keluarga. Hal ini perlu pendampingan hukum oleh pemerintah sehingga pihak-pihak yang bersengketa dapat menyelesaikan masalahnya secara tuntas, baik melalui jalan litigasi maupun non-litigasi. Selain itu, perlu dilakukan pembinaan kepada calok wakif terkait pengurusan sertifikat hak milik tanah yang akan diwakafkan, minimal berupa akta otentik yang dibuat oleh PPAT.

Ketiga, Program untuk Mendidik Masyarakat tentang Sertifikasi Tanah Wakaf. Sejumlah Lembaga sudah melakukan kegiatan untuk meningkatan pemahaman masyarakat tentang sertifikasi tanah wakaf. Mahmudi menceritakan tentang kegiatan di NU. NU mempunyai program yang berkelanjutkan. Kegiatannya adalah pendataan wakaf dan sosialiasai kepada masyarakat agar segera disertifikatkan. Kegiatan tersebut dilakukan dalam rangkaian kegiatan NU secara umum, seperti pengajian rutin. ${ }^{53} \mathrm{Hal}$ serupa disampaikan oleh Syarif yang menjelaskan kegiatan di Muhammadiyah. ${ }^{54}$ Para stakeholder yang concern di bidang wakaf harus memberikan pemahaman kepada calon wakif agar mengikuti prosedur perwakafan yang ditetapkan oleh undang-undang. Peningkatan

\footnotetext{
${ }^{48}$ Mahmudi, Wawancara, (Malang: 16 Juli 2019)

${ }^{49}$ Syarif, Wawancara, (Malang: 17 Juli 2019)

${ }^{50}$ Hamdani, Wawancara, (Malang: 14 Juli 2019)

${ }^{51}$ Mahmudi, Wawancara, (Malang: 16 Juli 2019)

${ }^{52}$ Syarif, Wawancara, (Malang: 17 Juli 2019)

${ }^{53}$ Mahmudi, Wawancara, (Malang: 16 Juli 2019)

${ }^{54}$ Syarif, Wawancara, (Malang: 17 Juli 2019)
} 
pengetahuan calon wakif dapat meningkatan kesadaran hukum sertifikasi tanah wakaf. Sebagaimana riset Adi Nur Rohman dkk. ${ }^{55}$

Melalui pendidikan yang diberikan baik secara formal maupun informal, ${ }^{56}$ kesadaran hukum masyarakat akan sertifikasi tanah wakaf akan muncul. Kesadaran hukum masyarakat terjadi tidak dapat terjadi dalam waktu singkat melainkan melalui proses yang panjang, yaitu proses internalisasi. Kesadaran hukum muncul karena substansi hukum selaras dengan nilai-nilai yang dipedomani. Atau hukum merubah nilai-nilai yang sebelumnya dipedomani. ${ }^{57}$ Kepatuhan hukum muncul atas dasar motivasi setelah seseorang memperoleh pengetahuan. Menurut Bierstend sebagaimana dikutip Amran Suadi, kesadaran hukum muncul karena proses sosialisasi, pembiasaan, dan kesadaran akan manfaat hukum. ${ }^{58}$ Ketiga, penguatan tim kerja sama wakaf (waqf task force). Tim pemerintah dan masyarakat harus membuat forum khusus penanganan kasus wakaf. Selama ini, task force penyelesaian wakaf sering diwacanakan namun belum juga terealisasi. Komunikasi yang terputus dan kebijakan yang belum aplikatif sering menimbulkan masalah sertifikasi belum tuntas. Kebijakan antar lembaga negara yang menangani sertifikasi tanah wakaf dan pemerintah daerah harus singkron. Misalnya kebijakan penghapusan tarif pajak BPHTB atau PBB terhutang untuk aset wakaf harus tertuang dalam Peraturan Daerah. Keberadaan task force menjadi urgen untuk segera dibentuk demi tercapainya sertifikasi tanah wakaf di Kota Malang secara maksimal dan tuntas, sebagaimana harapan Wali Kota Malang, Sutiaji.

\section{Kesimpulan}

Berdasarkan pembahasan di atas dapat disimpulkan bahwa: Ada dua faktor penyebab utama belum tersertifikatnya tanah wakaf di Kota Malang, yaitu pengetahuan masyarakat tentang wakaf masih rendah dan kompleksitas masalah wakaf yang dihadapi masyarakat. Berdasarkan hasil survey terhadap para takmir masjid di Kota Malang disimpulkan bahwa kesadaran hukum masyarakat masih perlu ditingkatkan. Hal ini merujuk pada kurangnya pengetahuan masyarakat peraturan wakaf yang berlaku di Indonesia. Banyak masyarakat yang tidak mengerti nama undang-undang wakaf. Adapun pengetahuan masyarakat tentang isi peraturan juga tidak terlalu tinggi. Meskipun demikian, berdasarkan survey ini juga diketahui bahwa antusiasme masyarakat melakukan akselerasi sertifikasi tanah wakaf tergolong cukup tinggi. Namun terkendala oleh persoalan waktu dan biaya pengurusan sertifikat.

Upaya untuk merevitalisasi kesadaran hukum masyarakat dilakukan dengan beberapa tahap. Pertama adalah sinergi lembaga secara mantap. Banyak lembaga yang berkecimpung di bidang wakaf. Namun, kerja mereka selama ini terkesan sendiri-sendiri. Andai saja semua bekerja sama sesuai dengan tugas dan fungsinya, upaya untuk pemaksimalan sertifikasi akan mudah terwujud. Tahap kedua adalah penyelesaian persoalan wakaf. Wakaf sering menimbulkan masalah . Wakaf yang

\footnotetext{
${ }^{55}$ Adi Nur Rohman et al., "Penyuluhan Hukum Tentang Urgensi Sertifikasi Tanah Wakaf Di Kelurahan Harapan Baru Kota Bekasi," Jurnal ABDIMAS (Pengabdian kepada Masyarakat) UBJ 2, no. 1 (January 15, 2019): 59, https://doi.org/10.31599/jabdimas.v2i1.425.

${ }^{56}$ Laurensius Arliman, Penegakan Hukum, 230-38.

${ }^{57}$ Amran Suadi, Sosiologi Hukum: Penegakan, Realitas, Dan Nilai Moralitas Hukum (Jakarta: Kencana, 2018),193.

${ }^{58}$ Suadi, 197.
} 
sebenarnya ditujukan untuk menambah aset umat ternyata sering membuat umat terpecah. Oleh sebab itu, upaya untuk menyelesaikan masalah wakaf dari hulu hingga hilir harus digalakkan. Terakhir, penguatan tim kerja sama wakaf (waqf task force). Tim pemerintah dan masyarakat harus membuat forum khusus penanganan kasus wakaf. Keberadaan task force menjadi urgen untuk segera dibentuk demi tercapainya sertifikasi tanah wakaf di Kota Malang secara maksimal dan tuntas.

\section{Daftar Pustaka:}

Abdi. "Kejar Bedah Rumah Dan Sertifikasi Tanah Wakaf." Malang Post Online. Accessed December 16, 2018. https://www.malangpostonline.com/read/8619/kejar-bedah-rumah-dansertifikasi-tanah-wakaf.

Arifin, Mohammad Syamsul. "Peranan Badan Wakaf Indonesia Dalam Penyelesaian Sengketa Tanah Wakaf." Jurnal Hukum dan Kenotariatan 4, no. 1 (March 7, 2020): 27-40. https://doi.org/10.33474/hukeno.v4i1.6446.

Badan Pusat Statistik Kota Malang. Kota Malang Dalam Angka 2019. Malang: BPS Kota Malang, 2019.

Disemadi, Hari Sutra, and Kholis Roisah. "Kebijakan Model Bisnis Bank Wakaf Mikro Sebagai Solusi Pemberdayaan Ekonomi Masyarakat." $L A W$ REFORM 15, no. 2 (September 30, 2019): 177-94. https://doi.org/10.14710/1r.v15i2.26176.

Fadhilah, Nur. "Sengketa Tanah Wakaf Dan Strategi Penyelesaiannya." De Jure: Jurnal Hukum Dan Syar'iah 3, no. 1 (June 1, 2011). https://doi.org/10.18860/j-fsh.v3i1.1321.

Fuadi, Nasrul Fahmi Zaki. "Wakaf sebagai Instrumen Ekonomi Pembangunan Islam." Economica: Jurnal Ekonomi Islam 9, no. 1 (July 31, 2018): 151-77. https://doi.org/10.21580/economica.2018.9.1.2711.

Hadiyanti, Anisa Rahma, Rachmad Safa'at, and Tunggul Anshari. "Kedudukan Akta Hibah Dalam Sengketa Kepemilikan Hak Atas Tanah." Lentera Hukum 4, no. 3 (December 14, 2017): 205-20. https://doi.org/10.19184/ejlh.v4i3.5316.

Hartono, C. F. G. Sunaryati. Peranan Kesadaran Hukum Masyarakat Dalam Pembaharuan Hukum. Bandung: Bina Cipta, 1976. repository.unpar.ac.id/handle/123456789/3019.

Havita, Gusva, and Gestivia Hakim. "WAKAF SAHAM DITINJAU DARI HUKUM ISLAM DAN PERATURANPERUNDANG-UNDANGAN SETELAH BERLAKUNYA UNDANG-UNDANG NOMOR 41 TAHUN 2004 TENTANG WAKAF." JURNAL SYARIKAH: JURNAL EKONOMI ISLAM 3, no. 1 (June 21, 2017): 358-71. https://doi.org/10.30997/jsei.v3i1.720.

Hendrawati, Dewi, and Islamiyati Islamiyati. "Penyelesaian Sengketa Tanah Wakaf Yang Tidak Tersertifikasi Di Wilayah Pesisir Utara Jawa Tengah." Masalah-Masalah Hukum 47, no. 1 (January 30, 2018): 71-80-80. https://doi.org/10.14710/mmh.47.1.2018.71-80.

Huda, Miftahul. "Wakaf Dan Kemandirian Pesantren Dari Tebuireng Hingga Gontor." ISLAMICA: Jurnal Studi Keislaman 7, no. 1 (January 23, 2014): 211. https://doi.org/10.15642/islamica.2012.7.1.211-231. 
Sudirman dan Ramadhita, Kesadaran Hukum Masyarakat...|49

Kasdi, Abdurrahman. "REINTERPRETASI KONSEP WAKAF MENUJU PENGEMBANGAN WAKAF PRODUKTIF." ZISWAF : Jurnal Zakat Dan Wakaf 2, no. 1 (August 19, 2016): 159-75. https://doi.org/10.21043/ziswaf.v2i1.1540.

Kementerian Agama RI. "Data Tanah Wakaf Kota Malang." Accessed May 11, 2019.

http://siwak.kemenag.go.id/tanah_wakaf_kab.php?prov=35\&kab=32.

- "Jumlah Tanah Wakaf Seluruh Indonesia." SIWAK KEMENAG RI. Accessed May 12, 2019. http://siwak.kemenag.go.id/tabel_jumlah_tanah_wakaf.php.

Koto, Alaiddin, and Wali Saputra. "Wakaf Produktif Di Negara Sekuler: Kasus Singapura Dan Thailand." Sosial Budaya 13, no. 2 (May 29, 2017): 116-39. https://doi.org/10.24014/sb.v13i2.3535.

Laurensius Arliman. Penegakan Hukum dan Kesadaran Masyarakat. Yogyakarta: Deepublish, 2015.

Leonando, Yose. "Penyelesaian Sengketa Wakaf Tanah Di Kecamatan Bayang Oleh Pengadilan Agama Kelas Ii Painan Kabupaten Pesisir Selatan." Al Hurriyah: Jurnal Hukum Islam 4, no. 2 (December 16, 2019): 178-191-191. https://doi.org/10.30983/alhurriyah.v4i2.1632.

Maulidi, Achmad Noer. "Wakaf Tunai, Implementasinya dalam Sistem Perbankan Syariah di Indonesia." IQTISHADIA: Jurnal Ekonomi \& Perbankan Syariah 4, no. 2 (December 29, 2017): 235-54. https://doi.org/10.19105/iqtishadia.v4i2.1225.

Medias, Fahmi. "Bank Wakaf: Solusi Pemberdayaan Sosial Ekonomi Indonesia." Indonesian Journal of Islamic Literature and Muslim Society 2, no. 1 (June 30, 2017): 61-84. https://doi.org/10.22515/islimus.v2i1.749.

Mei, Sukamto. "MENUJU ERA BARU WAKAF TUNAI (Sebagai Inovasi Finansial Islam dalam Mensejahterakan Umat)." MALIA (TERAKREDITASI) 9, no. 2 (June 5, 2018): 193-212. https://jurnal.yudharta.ac.id/v2/index.php/malia/article/view/1090.

Mulhadi, M, and Zulfi Chairi. "Analisa Yuridis Terhadap Kesadaran Hukum Berasuransi Pedagang Di Lingkungan Pasar Kota Medan." Mimbar Hukum 29, no. 2 (September 30, 2017): 235. https://doi.org/10.22146/jmh.17642.

Naimah, Naimah. "IMPLEMETASI YURIDIS TERHADAP KEDUDUKAN WAKAF PRODUKTIF BERBASIS PENINGKATAN EKONOMI MASYARAKAT DI INDONESIA." At-Taradhi: Jurnal Studi Ekonomi 9, no. 1 (August 1, 2018): 10-24. https://doi.org/10.18592/at-taradhi.v9i1.2093.

Niswah, Eva Mir'atun. "Problematika Yuridis Wakaf Hak Kekayaan Intelektual Di Indonesia." Volksgeist: Jurnal Ilmu Hukum Dan Konstitusi 1, no. 2 (December 31, 2018): 123-38. https://doi.org/10.24090/volksgeist.vli2.1907.

Oktaviani, Annisa, and Harjono Harjono. "Kekuatan Pembuktian Surat Letter C Dalam Pemeriksaan Sengketa Tanah di Persidangan." Verstek 7, no. 1 (May 15, 2019). https://jurnal.uns.ac.id/verstek/article/view/30038.

Rohman, Adi Nur, Sugeng Sugeng, Panti Rahayu, and Putra Perdana Ahmad Saifulloh. "Penyuluhan Hukum Tentang Urgensi Sertifikasi Tanah Wakaf Di Kelurahan Harapan Baru Kota Bekasi." Jurnal ABDIMAS (Pengabdian 
50 | De Jure: Jurnal Hukum dan Syar'iah, Vol. 12 No. 1 Tahun 2020

kepada Masyarakat) UBJ 2, no. 1 (January 15, 2019). https://doi.org/10.31599/jabdimas.v2i1.425.

Saidah, Hany. "Program Percepatan Sertifikasi Tanah Wakaf Untuk Pengamanan Aset Wakaf: Studi Di Kantor Kementerian Agama Kota Batu." Sakina: Journal of Family Studies 3, no. 2 (July 24, 2019). http://urj.uinmalang.ac.id/index.php/jfs/article/view/272.

Siddiq, Achmad. "Wakaf Produktif Dan Problematikanya Di Dunia Pesantren." Millah: Jurnal Studi Agama 11, no. 1 (2011): 275-89. https://doi.org/10.20885/millah.vol11.iss1.art14.

Soekanto, Soerjono. "Kesadaran Hukum Dan Kepatuhan Hukum." Jurnal Hukum \& Pembangunan 7, no. 6 (December 31, 1977): 462-70. https://doi.org/10.21143/jhp.vol7.no6.742.

Solihah, Cucu, Dedi Mulyadi, and Hilman Nur. "Muhammadiyah Nazhir Organization Analysis of Waqf Management and Development in Cianjur." Jurnal Dinamika Hukum 17, no. 2 (May 31, 2017): 125-31. https://doi.org/10.20884/1.jdh.2017.17.2.702.

Suadi, Amran. Sosiologi Hukum: Penegakan, Realitas, Dan Nilai Moralitas Hukum. Jakarta: Kencana, 2018.

Sudirman, Sudirman. "Studi Perbandingan Obyek Wakaf Menurut Fikih Dan Undang-Undang Wakaf." De Jure: Jurnal Hukum Dan Syariah 1, no. 2 (2010). https://doi.org/10.18860/j-fsh.v1i2.333.

Susanto, Heru. "Maqāṣid Al-Shar̄̄'ah on Wakaf System." HUNAFA: Jurnal Studia Islamika 14, no. 2 (December 31, 2017): 327-45. https://doi.org/10.24239/jsi.v14i2.486.327-345.

Syahputra, Akmaluddin, and Khalid Khalid. "Sengketa Tanah Wakaf di Sumatera Utara (Systematic Literature Review Terhadap Pemberitaan Media Online)." Halu Oleo Law Review 4, no. 1 (March 18, 2020): 13-24. https://doi.org/10.33561/holrev.v4i1.11525. 